Supplement of The Cryosphere, 12, 1523-1530, 2018

https://doi.org/10.5194/tc-12-1523-2018-supplement

(C) Author(s) 2018. This work is distributed under

the Creative Commons Attribution 4.0 License.

(c) (1)

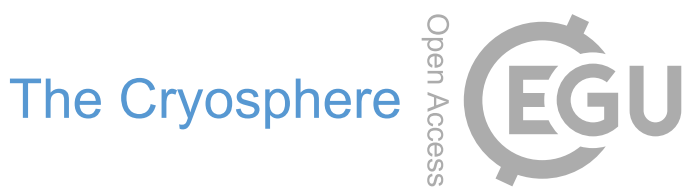

Supplement of

\title{
Brief communication: Unabated wastage of the Juneau and Stikine icefields (southeast Alaska) in the early 21st century
}

\section{E. Berthier et al.}

Correspondence to: Etienne Berthier (etienne.berthier@legos.obs-mip.fr)

The copyright of individual parts of the supplement might differ from the CC BY 4.0 License. 

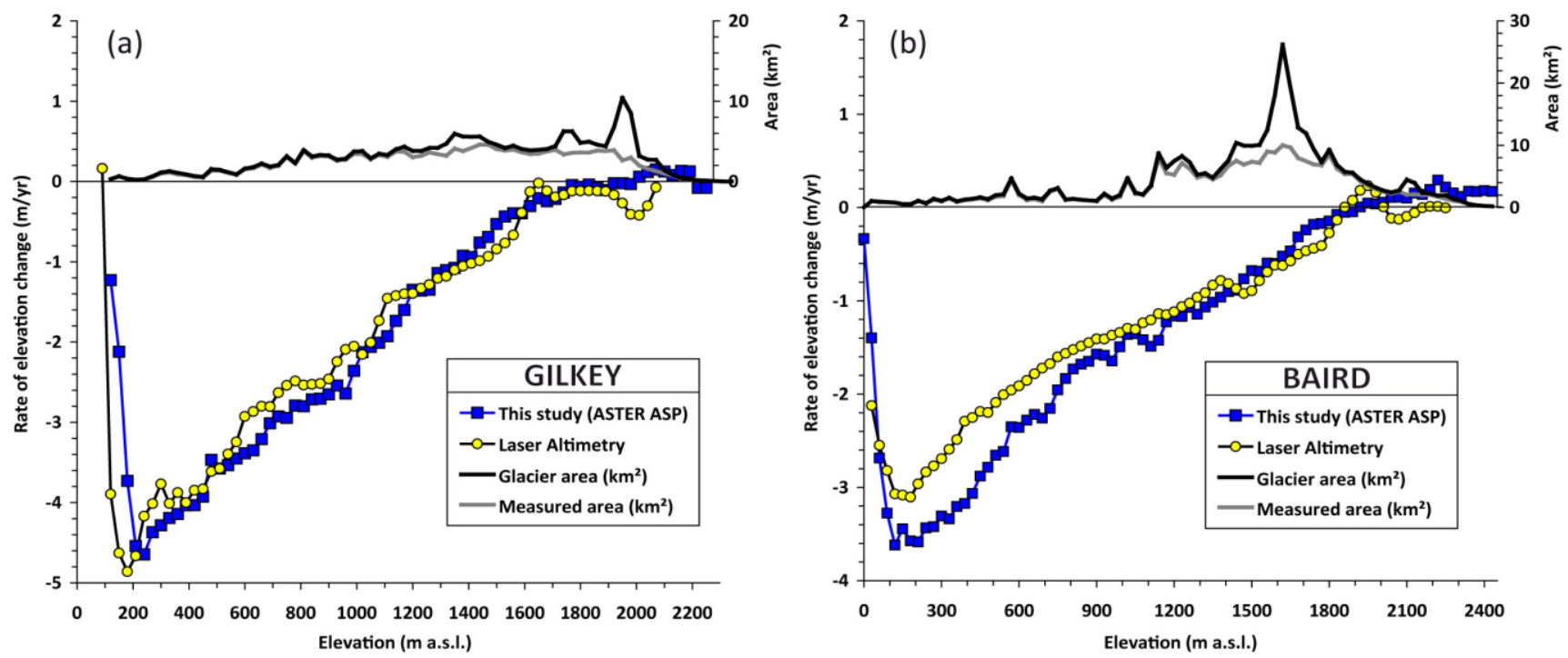

Supplementary Figure S1: Rates of elevation change vs. elevation for (a) Gilkey Glacier (Juneau Icefield) and (b) Baird Glacier (Stikine Icefield) measured from ASTER DEMs (blue curve, 2000-2016) and airborne laser altimetry data (2007-2012 for Gilkey and 1996-2013 for Stikine). The upper curve (right Y-axis) show the total area altitude distribution (black) and the glacier area effectively sampled using in the ASTER DEMs (grey).

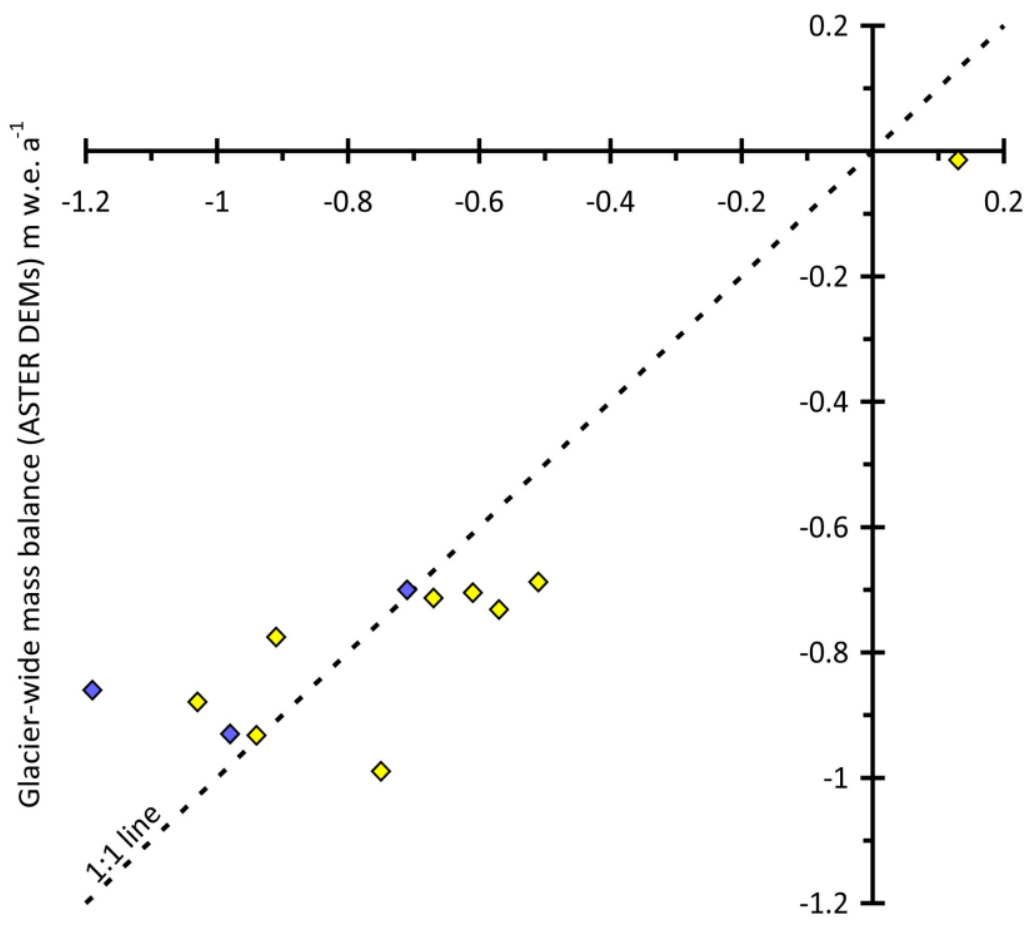

Glacier-wide mass balance (laser altimetry) $\mathrm{m}$ w.e. $\mathrm{a}^{-1}$

12 Supplementary Figure S2: Glacier-wide mass balances (Ba) of individual glaciers of the JIF (yellow, 9 glaciers) and SIF (blue, 3 glaciers) calculated in this study using ASTER DEMs from 2000 to 2016 and derived from airborne laser altimetry for different periods (Larsen et al., 2015). The dashed line is the 1:1 line. 